\title{
Brown starts debate with his report asking science to improve economy
}

Washington. When US Representative George Brown (Democrat, California) decided to write a report asking researchers to do more towards solving the nation's economic ills, he was looking for an argument. Thanks to an unauthorized draft shown to scientists attending a summer retreat last month, he got one sooner than he expected, setting the stage for lively hearings before his House science committee.

Science policy tends to be dry stuff, and congressional reports are plentiful. But Brown is counting on more than the usual rhetoric at a series of science policy hearings, and a provocative report seems just the thing to set the right tone. In a report* officially released this week, Brown and his staff call for a "rethink" of science priorities with a new emphasis on funding research that promises to contribute to "national priorities" such as economic competitiveness.

The idea is not new; in the 1970 s, the US National Science Foundation (NSF) operated a programme called Research Applied to National Needs. Nor is it, by itself, much of a threat to the status quo. Although Brown is an influential figure in Congress, he does not have the authority to change significantly the way US agencies spend billions of dollars on science.

But Brown's words, coming on the heels of new initiatives at NSF and the National Institutes of Health intended to orientate research priorities towards national economic and social needs (see Nature 358, 355; 1992 and 358, 661; 1992), may become a lightning rod for protests. US researchers have rarely before been asked to defend their work on anything but scientific grounds.

"It's down to the last blank check", Brown wrote last week in the Los Angeles Times in an opinion piece timed to accompany the release of the report. "We've paid for 45 years of discovery; let's start requiring its application to the critical problems in the civilian sector." Brown wants to measure the value of research "not by number of publications or citations or patents, but by progress towards specific [national] goals", and some of his examples could further raise scientific eyebrows: "greater opportunity for self-realization", "less dependence on material goods as a gauge of wealth or success" and "less armed conflict".

Brown takes a somewhat more sober tone in his committee report, although his conclusion is the same. He says the government should define the national goals towards which research should be expected to contribute. Science agencies should com-

mission independent "performance assessments" to determine what research contributes most to the national goals. And the White House's Office of Science and Technology Policy (OSTP) should become the "command center" for implementing and evaluating all research policy decisions.

Those who read a leaked draft of the

“We've paid for 45 years of discovery; let's start requiring its application to the critical problems in the civilian sector."

US Rep. George Brown

\section{"He blames science for what are really the failings of the political process."}

David Baltimore

report at a meeting last month (an interdisciplinary conference held on 15-21 August at the Keystone Center in Keystone, Colorado) were incensed by its tone. The document "blames science for what are really the failings of the political process", says Nobel prizewinning biologist David Baltimore. "It misses the whole point about science being forward-looking, it is vague about its goals and the actions it proposes are pure bureaucracy." Many of the solutions Brown proposes as alternatives - such as block grants, grants based on past performance and funding decisions by 'smart managers' - have been tried in Europe with limited success, he says.

Social scientists have also had little success in trying to calculate the impact of particular research projects. That aspect of Brown's proposal, says Roland Schmitt, the president of Rensselaer (New York) Polytechnic Institute and a member of the National Science Board, which oversees the NSF, is "going to require a lot of discussion".

Much of the outcry appears to be based on the source of the report; Brown has been a strong supporter of science in the US Congress and has often provided a counterweight to attacks from US Representative John Dingell (Democrat, Michigan) and others. The fact that Brown is now questioning the basic premise of US research policy is unsettling.

Brown would like his report to prompt a fierce debate of the issues. Running for reelection in the autumn in what is expected to be a close race, Brown hopes his strong words will at least inspire his successors if he cannot attempt to legislate such radical changes himself. The test of that strategy will begin on 24 September at the first of a series of hearings before the committee.

Christopher Anderson

* Report of the Task Force on the Health of Research Committee on Science, Space and Technology, US Congress, 1992 .

\section{NEJM restricts use of SI units}

Washington. Responding to the wishes of its readers, the New England Journal of Medicine (NEJM) has dropped its preference for Systéme Internationale (SI) units in scientific measurements. Beginning in July, units more common in the United States became the standard rather than appearing only upon the request of the author. Meanwhile, SI units have been relegated to parentheses - and have almost disappeared from tables and charts. One major shift was to express cholesterol levels in milligrams per decilitre instead of millimoles per litre.

The move reverses a decision made several years ago by NEJM and many other US medical journals to emphasize SI units because they are more informative and also more commonly used. But US physicians, commercial laboratories and hospitals have resisted the switch, and the NEJM concluded that it was "unwise to publish in one system while most of our readers use the other system in their practices."

So far, no other journal has followed suit. For instance, the American Medical Association says it is sticking with SI units because the readership of its journals is evenly divided between the United States and the rest of the world.

NEJM's retreat has outraged some, especially in Europe. An editorial last month in the British Medical Journal compared the NEJM's decision to "the World Health Organization deciding that trying to eradicate polio is just too tiring".

Edward Campion, an NEJM deputy editor and author of the editorial announcing the decision, called the controversy "a tempest in a teapot". He said the change affects only "which [unit] comes first in the parentheses."

Traci Watson 